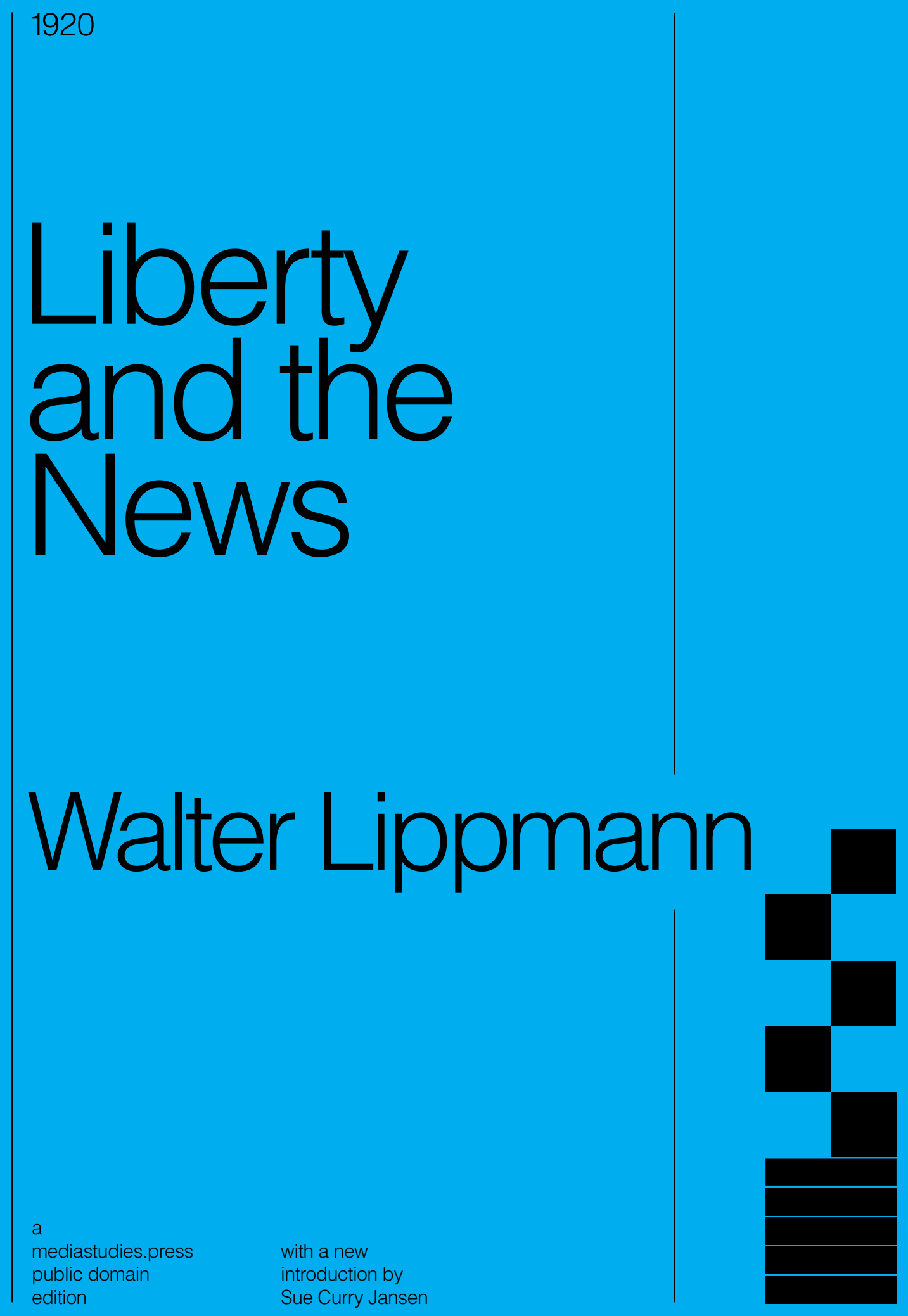




\section{Walter Lippmann}

\section{LIBERTY AND THE NEWS}

A MEdiastudies.PRESS PUBLIC DOMAIN EDITION 
Liberty and the News, originally published in 1920 by the HARCOURT, BRACE AND HOWE, is in the public domain.

Published by mediastudies.press in the pUblic domain series

mediastudies.press I 414 W. Broad St., Bethlehem, PA 18018, USA

New materials are licensed under a Creative Commons Attribution-Noncommercial 4.o (CC BY-NC 4.o)

COver Design: Mark McGillivray

Copy editing: Petra Dreiser

CREDIT FOR SCAN: Internet Archive, from the collections of the University of Michigan, 2008 upload CREDit fOR LATEX template: Book design inspired by Edward Tufte, by The Tufte-LaTeX Developers ISBN 978-1-951399-02-3 (print) | 978-1-951399-03-o (ebook)

DOI $10.32376 / 3 \mathrm{f} 8575 \mathrm{cb} .2 \mathrm{e} 6 \mathrm{eg} 142$

LIBRARY OF CONGRESS CONTROL NUMBER 2020950484

Edition 1 published in November 2020 


\title{
THE TWIN CRISES OF DEMOCRACY AND JOURNALISM \\ Introduction to the mediastudies.press edition
}

\author{
Sue Curry Jansen
}

Liberty and the News was published a century ago this year. A small

doi book-consisting of two essays previously published in the Atlantic Monthly, joined together by a short introductory chapter-it seemed an unpretentious offering by Walter Lippmann (1889-1974). It was young Lippmann's fifth book, and, as a compilation, commentators have long considered it a minor work. Yet the questions it raised about journalism and democracy became the catalyst for a period of generative thinking by the author, leading to his classic, Public Opinion (1922), and its sequel, The Phantom Public (1925). The issues this little book identified would continue to influence Lippmann's thinking about the role of the media and the public throughout his long life. ${ }^{1}$

Lippmann wrote Liberty in the immediate aftermath of his military service in France and his attendance at the peace negotiations in Versailles as an assistant to Colonel House, President Woodrow Wilson's chief advisor. Like so many members of the so-called Lost Generation, Lippmann felt deeply disillusioned by his wartime experiences. Liberty marked his initial attempt at coming to terms with the chasm that separated the idealism that had attracted him to a career as a journalist and public intellectual, and the systemic barriers that too often undermined the values fueling that idealism. Lippmann, who always chose his words carefully, referred to these obstacles as "censorships."

Lippmann's use of the term censorship has not received adequate attention in the voluminous analyses and critical commentaries penned by generations of readers and interpreters. Yet censorship

\footnotetext{
${ }^{1}$ Walter Lippmann, Public Opinion (New York: Harcourt, Brace and Co., 1922); and Lippmann, The Phantom Public (New York: Harcourt, Brace and Co., 1925).
} 
was a pressing public issue when Lippmann wrote Liberty, as was its counterpart, propaganda. Both vividly shaped the author's immediate experiences during World War I.

Lippmann was one of the founding editors of the New Republic in 1914-a magazine that published many of America's most influential intellectuals. Its editorial board had supported Wilson's re-election in 1916 and strongly favored U.S. entry into the war. In preparation for the mobilization of troops, Colonel House asked Lippmann to prepare a memorandum on wartime information policy. In response, Lippmann recommended that the Wilson administration set up an official news bureau that would provide the public with accurate information, and identify and discredit rumors and falsehoods. He also urged the administration to avoid arbitrary censorships. Lippmann recognized that some censorship was necessary during wartime to protect the troops, but contended that "protection of a healthy public opinion" was of "first importance." ${ }^{2}$ Wilson was not persuaded. Instead, the president authorized the creation of the Committee on Public Information (CPI), which insiders at the time referred to colloquially as the "Ministry of Information."3 The CPI was headed by George Creel, a former journalist whom Lippmann had heavily criticized for some of his coverage of the 1913-1914 Colorado coalfields labor conflicts that included what came to be known as the Ludlow Massacre.

The CPI developed into a propaganda behemoth with more than thirty divisions, including a censorship board; it exercised unprecedented influence over well-nigh every aspect of American life. Every available form of media was used to support the CPI's messaging, with the help of writers, journalists, artists, cartoonists, the film and advertising industries, clergy, school teachers, citizen volunteers, social clubs, and virtually everyone who had an audience, no matter how small. News was censored following "voluntary" rules that sanitized and glorified the war. Other U.S. government entities also imposed restrictions on free expression. Congress enacted alien and sedition acts. The postmaster assumed the role of censor by refusing to send through the mail socialist and other periodicals deemed offensive. Massive deportations of foreign-born war critics ensued; prominent war protesters, including the former presidential candidate Eugene Debs, were arrested and given long prison sentences; radical college professors were fired; and with mounting war hysteria, fanned by the CPI, discrimination against German Americans increased as well. Lippmann himself completed his military service in a propaganda unit in France, composing leaflets that urged German soldiers to surrender and interviewing German prisoners of war.

\author{
${ }^{2}$ Quoted in Ronald Steel, Walter Lipp- \\ mann and the American Century (Boston: \\ Little, Brown and Co., 1980), 125. \\ ${ }^{3}$ James R. Mock and Cedric Larson, \\ Words That Won the War: The Story of \\ the Committee on Public Information, \\ 1917-1919 (Princeton, NJ: Princeton \\ University Press, 1939).
}


By 1920, censorship amounted to more than an intellectual and professional concern for Lippmann; it had a visceral meaning for him, fueling his heated rhetoric. That year, he also published as a supplement to the New Republic a study of self-censorship by the press, co-authored with his longtime friend and colleague Charles Merz and titled "A Test of the News."4 Pioneering content analysis as a method for assessing media bias, Lippmann and Merz analyzed coverage of the Russian Revolution in the New York Times. "A Test" was more than twice as long as Liberty; it examined more than 3,000 Times articles covering Russia from March 1917 to March 1920. The overall conclusion? The Times, one of America's most trusted news sources, failed the test. According to Lippmann and Merz, the paper's news coverage of Russia was "dominated by the hopes of the men who composed the news organization." The journalists saw what they wanted to see, not what was actually happening. Lippmann and Merz concluded that "the chief censor and chief propagandist were hope and fear in the minds of the reporters and editors." 5 Their desire to win the war and see the revolution defeated led them to systematically misrepresent the facts in Russia.

Today, we should read "A Test of the News" as a companion to, or even a missing chapter of, Liberty. It provided Lippmann with credible empirical evidence to support the arguments he developed in Liberty-arguments both prospective and retrospective. Lippmann worried that the kinds of practices that had made "the manufacture of consent" possible on an unprecedented scale during the war were becoming normalized in peacetime. The CPI had recruited thousands of cultural workers as volunteers to the government's propaganda effort: journalists, advertisers, illustrators, writers, actors, etc. New forms of mass media-radio and film-had greatly amplified the reach of their work. By 1920, the commercial potential of these new media, and the enhanced persuasive techniques developed by CPI staff and volunteers, were already being exploited by the private sector.

Lippmann focused specifically on how the kinds of bias that had distorted the Times coverage of the Russian Revolution were becoming the postwar norm. He contended that the work of reporters had become "confused with the work of preachers, revivalists, prophets and agitators." He added, "The current theory of American newspaperdom is that an abstraction like the truth and a grace like fairness must be sacrificed whenever anyone thinks the necessities of civilization require the sacrifice." Lippmann specifically called out Adolph Ochs, the owner of the New York Times, and Lord Northcliffe, a British newspaper magnate and wartime director of propaganda, as newspaper owners who "believe that edification is more important than
${ }^{4}$ Walter Lippmann and Charles Merz, with the assistance of Faye Lippmann, "A Test of the News," New Republic, August 4, 1920, 3.

\footnotetext{
${ }^{5}$ Lippmann and Merz, "A Test of the News," 3 .
} 
veracity. They believe it profoundly, violently, relentlessly. They preen themselves upon it." 6

Lippmann accused the men of putting "a painted screen where there should be a window to the world." Because democratic governance requires citizens to have access to truth, he accused both public and private censors and propagandists of "attacking the foundations of our constitutional system." Lippmann, whose mentors included the philosophers William James and George Santayana, was not naive about the nature of truth: He recognized that in a secular age people are "critically aware of how their purposes are special to their age, their locality, their interests, and their limited knowledge."7 $\mathrm{He}$ would ultimately arrive at a Peircean conception of truth-although some interpreters mistakenly impute a simplistic theory of journalistic objectivity to him. ${ }^{8}$ According to Lippmann, the painted screens have left the public "baffled because facts are not available; and they are wondering whether government by consent can survive in a time when the manufacture of consent is an unregulated private enterprise." For, he contended, "in an exact sense the present crisis of western democracy is a crisis in journalism." 9

It is in this context that we can understand Lippmann's distinctive definition of liberty, which has puzzled many readers and interpreters through the years. For Lippmann, liberty constitutes a method, not a series of prohibitions and permissions: "Liberty is the name we give to measures by which we protect and increase the veracity of the information upon which we act." The critical purpose of Liberty and the News, then, is to identify and examine specific political, sociological, and technological obstacles ("censorships") that undermine the veracity of the information provided by the news. The book's constructive project means to identify and examine potential reforms-ethics, policies, and practices-that may increase the reliability of the news. Because, Lippmann concludes, "there can be no liberty for a community which lacks the information by which to detect lies."10

That conclusion appears as resonant in 2020 as it was in 1920. Almost eerily so, as the prominent writer and journalism teacher Roy Peter Clark testifies. He reports serendipitously coming across a weathered copy of Liberty and the News in a library storage room. This was his first encounter with the book, although he of course knew Public Opinion. He prefaces his response to Liberty with an unscholarly "Wow," and describes the immediacy of its message for the current plight of the press and the public. "In a single day," Clark writes, "I read the text, making notes about almost every page. What I learned startled me, like discovering an ancient scroll meant to be found a century into the future, unearthed just in time to rescue civilization from catastrophe."11
${ }^{6}$ Lippmann, Liberty and the News, 2,3 .
Page references are to the mediastud-
ies.press edition.

7 Lippmann, Liberty, 3, 4 .

${ }^{8}$ Walter Lippmann, The Public Philosophy (Boston: Little, Brown and Co., 1955). For Lippmann, as for Charles Sanders Peirce, truth is socially constructed dialogically by a community that shares common epistemological standards. Through ongoing critique, it gradually produces more reliable knowledge over time.

${ }^{9}$ Lippmann, Liberty, 1 .

${ }^{10}$ Lippmann, Liberty, 21, 20.

${ }^{11}$ Roy Peter Clark, "Walter Lippmann on Liberty and the News: A CenturyOld Mirror for our Troubled Times," Poynter, March 1, 2018. 